\title{
Sosyal Sorumluluk Bağlamında, Dünyada “Kadına Yönelik Şiddete Hayır" Temalı Sosyal Medya Kampanyaları ve Aktivizm Örnekleri
}

\author{
Ali KARATAY \\ Ayşe KARATAY**
}

\begin{abstract}
Özet
Kadına yönelik şiddetin, dünya üzerindeki göz ardı edilemez gerçekliğini ele almak ve sanatsal bağlamda sosyal medya kampanya örnekleri yoluyla tartışmak amaciyla hazırlanan bu projede dünya üzerinde, ülkelerin gelişmişlik düzeyi ne olursa olsun; kadının sosyo-kültürel çevresi, bireysel maddi bağımsızlı̆̆ı, eğitim seviyesi, inancı ve yaşam tarzına bakılmaksızın maruz kaldığı şiddetin, farklı sanatsal sosyal medya çalışmaları yoluyla incelenmesi amaçlanmaktadır. Ayrıca şiddetin fiziksel, psikolojik, sözel ve cinsel türleri üzerinde yapılan çalışmaları irdeleyerek, sosyal açıdan farkındalık sağlayan çalışmalara atıfta bulunulacaktır. Çalışma sırasında söz konusu amaçlara uygun literatür ışığında betimsel-tarama yöntemiyle yapılandırılmıştır. Öte yandan konu ile ilgili çok sayıda sosyal medya çalışması seçkili örneklem yöntemi ile incelenmiştir. İncelenen çalışmalar, uygulama alanlarına ve bölgesel bakış açlarına göre yorumlanmıştır.

Araştırmada kadına yönelik şiddetin ve şiddetin her türünün dünya üzerindeki negatif toplumsal etkisi ve bu etkinin sanatsal anlamda dışavurumunun, toplum bilinçlenmesi ve bakış açısının şekillendirilmesi sürecindeki pozitif tepkileri gözlemlenmiştir. Ve çalışmaların, sosyal sorumluluk bilinciyle ele alınarak, gerek sivil toplum kuruluşları gerekse sosyal bilinçlenmeye duyarlı kurumsal şirketler tarafından desteklendiği görülmüştür. Sosyal medyanın küçümsenemez etkisi ile belirli bir kesim veya toplum için üretilmiş sosyal medya çalışmaları "evrensel" şiddet olgusuna karşı bilinçlenmeye ve tepkilerin özgürce dışa vurumuna zemin oluşturmuştur. Sanatın toplum bilinci üzerindeki etkisi; görsel ve algısal yapısıyla sosyal mesajları etkin ve etkili biçimde iletimi ve mesajın "hareket (acting)" hali, bu araştırmayla sunulmaya çalışılmıştır.
\end{abstract}

\footnotetext{
* Dr., Dokuz Eylül Üniversitesi Güzel Sanatlar Fakültesi Film Tasarımı Bölümü Canlandırma Filmi Ana Sanat Dalı

** Dumlupınar Üniversitesi Sosyal Bilimler Enstitüsü Grafik Ana Sanat Dalı Yüksek Lisans Programı
} 
Anahtar Kelimeler: Sosyal Medya, Kadına Yönelik Şiddet, Kadın, Sosyal Sorumluluk.

\title{
No Violence Against Women" Themed Global Social Media Campaigns and Activism Samples in the Context of Social Responsibility
}

\begin{abstract}
The purpose of this project are obvious violence against women, debate about art and social media, Regardless of how developed the country is (depending on women's socio-cultural environment level of education belief and religion, irrespective of exposure violence and lifestyle of women) result of different art and social media. In addition, abuse of the physical, psychological, verbal and sexual nature by examining the work done on the social aspects will be referred to studies that provide awareness. During the study of literature according to that objective has been structured with method descriptive-scanning. Furthermore, a large number of relevant social media examples were examined by sampling method.

In the study of violence against women, and all forms of violence and negative social impact on people, and this effect of expression in the artistic sense, awareness and perspective of society in the process of shaping positive responses were observed. And both non-governmental and social organizations have been supported by corporate companies. With the impact of social media which cannot be underestimated have provided basis for a certain segment and community. Impact on community awareness of art; with visual and perceptual structures efficiently and effectively transmit social messages and the message was "movement (acting)" state, in this study has attempted to present.
\end{abstract}

Key Words: Social Media, Violence against Woman, Woman, Social Responsibility.

\section{Bölüm: Geçmişten Bugüne Kadın ve Kadına Şiddet}

\subsection{Geçmişten Bugüne Kadın}

Kadın, hâlihazırdaki toplumsal yapının temel taşıyıcısı olan "aile"yi biçimlendiren, etkileyen temel unsur olmakla kalmayıp, kültürel mirasın geçişinin anahtarı ve gelecek nesillerin hazırlayıcısı rolünü her çağda üstlenen bir konuma sahip olmuştur. Bu nedenle de, kadın kimliğinin geçirdiği değişimler, yapı bozumları ve bunların dolaylı olarak neden 
olabileceği psikolojik açmazlar, sadece kadını değil tüm popülasyonu etkilemektedir (Tayanç, 2010).

Kadınlar ve erkekler toplumsal birer varlıktır ve doğumlarından itibaren toplum her iki cinse de bazı rol, davranış kalıpları atfeder. Her iki cinse aktarılmış olan bu rol modelleri, toplum tarafından kabul edilmiş doğrular olarak görülür. Bu nedenle, kadının ve erkeğin olduğu her yerde toplumsal cinsiyete (Social Gender) dair bu tür rol düzenlemelerinin de yer alacağını söylemek mümkündür... Sosyal ortamın genel özellikleri kadın kimliğinin oluşum sürecinde etkili olmaktadır (Sankır, 2010).

İçerisinde var olduğu toplumsal yapıdan beslenerek oluşan/oluşturulan kadın kimliği, kadının; aileyi biçimlendiren, kültürel mirasın nesiller arası geçişini sağlayan ve gelecek nesillerin hazırlayıcısı olan gibi özelliklerinden dolayı toplumların dinamiklerini de şekillendirmektedir. Bu nedenledir ki kadın kimliği, insan ırkının var olduğu ilk günden bu güne "-geniş/uzun bir zaman dilimi içinde, olumsuz ve ciddi bir biçimde- toplumu etkiler, etkileyecektir." (Tayanç, 2010).

Bir kimlik olarak kadın tanımlaması toplum ve kültürlerden ziyade bir zihniyet bir algı problemi olarak karşımızda durmaktadır. Aynı toplum içerisinde ortaya çıkan farklı kimlikler ve kültürler bu kimlik ve kültürlerin ürettiği kadın algıları ve bu algıların nesiller arası aktarımları bu çıkarıma bizi sürüklemektedir.

Tarihi gelişim süreci içerisinde ya da içerisinde hayat bulduğu sosyo-kültürel konum kadını geçmişten bu güne tanımlamamıza yardımcı olmaktadır.

\subsection{Kadına Bakış}

İnsan, biyososyopsikolojik bir varlıktır. Toplumların ve kültürlerin geçirdiği değişim süreçlerinden, bireyin etkilenmemesi söz konusu değildir. Sosyolojik değişim süreçlerinin etkilerinin, en bariz biçimde görüldüğü alan ise, "kimlik" kavramı alanıdır (Tayanç, 2010).

Geçmiş ya da günümüz olarak zamansal bir ayrıma gitmeden kadın kimliğini ve kadına yönelik bakışı insanlar ve algılar üzerinden değerlendirmek; tarihsel süreç içerisinde kadının gördüğü şiddetin, kadına yönelik sınırlamaların ve kadının sahip olduğu kimliğin ya da kadına yüklenen anlamın geleneksel ya da modern yaşam standartlarında birbirini tekrar etmesi açısından (göstergelerin farklılık arz etmesi bu çıkarımı değiştirmemektedir), doğru bir çıkarım olarak karşımızda durmaktadır.

Kültür, ekonomi, nüfus, politika, fiziki çevre, sosyal sınıf ve etnik köken farketmeksizin cinsiyet ayrımının başladığı günden bu güne kadın 
kimliği dişlanmakta, kadın şiddet görmekte, cinsel bir obje olarak sunulmakta, anne olmakla değer bulmakta, el üstünde tutularak kadınlığıyla saygı görmekte ya da kadın kültürel bir obje olarak değerlendirilmekte, hiç olmaması gereken bir varlık olarak sorunların tek kaynağı olmakta ve genellikle kadın ikincil konumda kalmakta birincil olduğu ve kendi kimliğine sahip olduğu anlarda ise bu kazanımını yine erkek bakışın izin verdiği sınırlar içerisinde elde etmektedir.

Açık bir ifade ile kimlik belirleyen konumunda bulunan değişkenlere rağmen kadın kimliğine yönelik bakış ve kadının ikincil planda kalan konumu değişmemektedir.

...Bir annenin dışsallaştırmış olduğu kimlik, kızı tarafından içselleştirilir. Bu içselleştirme aşamasında kız çocuğu, bir yandan kendi kimliğini kazanırken, diğer yandan kız çocuğunun nasıl kadın olarak, oğlan çocuğunun da nasıl erkek olarak yetiştirileceğini öğrenir ve kendisi bir anne olduğunda da toplum tarafından kendisinden beklenen rolü oynar. Kısacası, geleneksel kadın kimliği şeyleşmiştir ve gündelik hayatın döngüsü içerisinde sorgulanmaksızın nesilden nesle aktarılmaktadır (Metin, 2011).

Fakat bu aktarım kimlik bunalımının görülmediği insanlarda sağlıklı gerçekleşmektedir. Oysa geçmişte ya da günümüzde bir çok insan için kimlik bunalımından söz etmek mümkündür. Kimlik bunalımı geçmişte erkek egemen bakışla açığa çıkarken günümüzde tv, internet, dergi gibi kitle iletişim araçları ile hayat bulmaktadır.

Özellikle kimlik bunalımı, rol karmaşası, sosyo-politik ve sosyoekonomik problemler kimlik aktaran konumundaki nesilleri işlevsiz hale getirmiştir. Bu problemler çözüme kavuşmadı̆̆ gibi sağlıklı bir toplumu meydana getiren kültürel aktarımı alamayan genç nesiller de bu açığı internet, Tv, sinema gibi kitle iletişim araçları ile doldurmaktadırlar. Ve bu durum özellikle algıları şekillendirerek kadını ikincil konumlandırmaktadır.

\subsection{Algı Sorunu ve Kadına Şiddetin Nedenleri}

Felsefe alanında sorulan temel sorulardan birisi, gerçeğin ne olduğudur. Sorunun tek bir kesin ve doğru cevabı da yoktur. Sorunun doğru cevabına ilişkin yapılan tartışmalar genellikle "duruma göre değişir" şeklinde sona erer. Ayrıca sorunun cevabına sosyal yapı ekseninde, görüş birliği ve inanç yapıları temel alınarak ulaşılabileceği de söylenebilir (Friman, 1999: 6). Gerçek kavramından yola çıkarak algının, nesneler ve nesneler arasında gerçekleşen bilinçli deneyimler olduğu söylenebilir (Coren vd., 1993: 17). Bu kapsamda bir kişiye göre doğru olan, farklı durumlarda aynı kişiye doğru gelmeyebilir. Benzer şekilde bir kişi için doğru görülen, bir başkası için doğru olmayabilir. Bu anlamda gerçek kavramının; bölgeden 
bölgeye, ülkeden ülkeye, hatta kişiden kişiye göre değişiklik gösterdiği için tek bir doğru olmadığı söylenebilir. Bu yüzden kişilerin algıladıkları gerçekler farklılık gösterebilmektedir (Friman, 1999: 6). Bu durum kişilerin olaylara bakış açılarının farklı bölgeler, farklı kültürler ve farklı kişilikler gibi bir takım nedenlerden ötürü farklılaşması sonucunu ortaya koyar (akt: Bakan, Kefe, 2013).

Algı, duyu organlarımızca taşınan duyusal verileri örgütleyip yorumlamaktadır. İnsanların çevresindeki yer alan uyaranlara anlam verme sürecidir (Arkonaç, 1998: 65). Algı ayrıca; diş dünyadan gelen uyarıların, zihinsel olarak yorumlanması olarakta tanımlanabilir. Algılar; ne gördüğümüzü, nasıl yorumladığımızı, neye inandığımızı, nasıl davrandığımızı bize göstermektedir. Algılarımız aynı zamanda zihnimizde değerler yaratmakta, problemler oluşturmakta ve bu problemleri de çözmektedir. Bu kadar güçlü bir özelliğe sahip olan algılarımız, birçok psikolog tarafından, "gerçek" olarak nitelendirilir (Johansson ve Xiong, 2003: 232; Willimon, 2000: 22) (akt: Bakan, Kefe, 2013)

Erikson'a göre kimlik kazanımı süreci, ergenlikten çok önce başlar ve önceki dönemlerde başarılı sonuçlar alınmış ise, yetişkin kimliğine geçiş kolaylaşır. Böylece bedeni, çok kısa bir süre içinde yetişkin görünümü alan ergen artık çocuk gibi davranamayacağını anlar ve "ben kimim?", "değerlerim neler?", “yaşamdaki amaçlarım nedir?" gibi sorularla geleceğe dönük kararlar alarak kimliğini kazanmaya başlar. Ergenin bu çabaları yetersiz kaldığında, kimlik krizi çözümlenemez ve sonuçta ergen kimlik karmaşası yaşayabilir veya olumsuz bir kimlik geliştirebilir (Sayıl, 2004) (akt: Sarıkaya, 2014).

Kimlik; bireyin fiziksel, bilişsel, sosyal ve psikolojik gelişiminin birbiriyle ilişkili olarak ilerlemesinin sonucunda oluşturulur (Köker, 1997, s.1). Bu nedenle kimlik çocukluğun ilk yıllarının ardışık özdeşimlerinin toplamını, hatta daha fazlasını içerir. Kimlik, ergenlikte yaşıtlarla ve aile dışı lider figürlerle yeni özdeşleşmeler içinde çözülen krizin biricik ürünüdür (akt:Adams, 1995, s.74). Erikson'un kuramını temel alarak çalışmalar yapan Marcia'ya göre ise kimlik bireyin yeteneklerini, inançlarını ve bütün yaşamını kapsayan içsel, birey tarafından yapılandırılan dinamik bir yapıdır. Bu yapı ne kadar iyi gelişirse birey kendi özelliklerinin ve bireyselliğinin o kadar farkında olur. Bu yapı ne kadar az gelişirse kişi kendisini başkalarından ayırt eden özelliklerini anlamada karmaşa yaşar. Kendisini değerlendirirken başkalarının görüşüne güvenir (akt: Süslü, 2002, s.8-13) (akt: Sarıkaya, 2014) 
Kişilerin kendilerini hangi kimliğe dahil edeceklerini bilememesi ve kendisini başkalarına göre şekillendirmesi kişinin kimlik bunalımına neden olmaktadır. Zamanla yetersizlik duygusunun hakim olacağı bir sürece giren, kimlik bunalımına sürüklenen bu kişi söz konusu eksikliğini erkini kolaylıkla ispat edebileceği şeylerle gidermeye çalışacaktır.

Geçmiş ya da bugün fark etmeksizin, ortaya çıkan kimlik bunalımı ve eksiklik duygusu erkeklerin kadınlar üzerinde kadınların da diğer kadın ve erkekler üzerinde egemenlik kurması ve onları şekillendirmesi ile sonuçlanmaktadır.

Kadına yönelik şiddet, cinsiyete dayanan, kadını inciten, ona zarar veren, fiziksel, cinsel, ruhsal hasarla sonuçlanma olasılığı bulunan, toplum içerisinde ya da özel yaşamında ona baskı uygulanması ve özgürlüklerinin keyfi olarak kısıtlanmasına neden olan her türlü davranıştır (DSÖ, 1993)(akt: Subaşı, Akın, 2011)

Kadına yönelik şiddet, yaşam döngüsü içinde ele alındığında, daha konsepsiyon öncesi dönemde başlamaktadır. Aile içinde sahip olunacak çocuğun cinsiyetinin kız çocuklar aleyhine belirlenmesi, kız bebeklerin öldürülmesi, kız çocuklarının cinsel istismarı, dövülmesi, çeyiz, başlık parası, namus cinayetleri, flörtte şiddet, evlilikte hırpalanma, dayak tecavüz, ekonomik ve psikolojik baskı, genital mutilasyon ve diğer cinsel organlara zarar verici uygulamalar, işyerinde ve diğer kurumlarda cinsel ve psikolojik şiddet, kadın ticareti, fahişeliğe zorlama, yaşlılıkta fiziksel, cinsel ve psikolojik saldırıya uğrama, cinayete kurban gitme şeklinde gerçekleşmektedir (Heisse, 1994) (akt: Subaşı, Akın, 2011).

Toplum ve kültürler farklılık gösterse de farklı kültürlerde ve toplumlarda kadına yönelik şiddet türlerinin benzerlik göstermesi bizi kadına yönelik şiddetin nedenlerini kimlikler üzerinden değerlendirmemiz gerektiği gerçeğine götürmektedir. Burada şiddet uygulayan insanlarda görülen kimi ortak özellikleri ifade etmek gerekir. Bu özellikler;

- Düşük benlik saygısı.

- Sıklıkla terkedilme, kayıplar, yardımsızlık, bağımlılık, güvenlik duygusunda azalma, mahremiyet ile ilgili sorunlar yaşamaktadır.

- Kişilik bozukluğu tanısı alanlara sık rastlanmaktadır.

- Engellenmeye karşı düşük tolerans gösterirler.

- İstismar ve şiddetin bulunduğu ailelerde büyümüşlerdir.

- Kendi davranışları ile ilgili inkar, küçümseme, iddiacı ve yalana yönelme şeklinde bir tutum içindedirler.

- Şiddet konusundaki görüşlerine bütün dünyanın katıldığını ve şiddetin günlük hayatla baş etme yollarından biri olduğu görüşündedir. 
- Empati yapma yeteneği zayıftır.

- Kadın ve erkek davranışları konusunda katıdırlar.

- Sıklıkla kendisini "özel" olarak görmekte, koruyucu ve bakım verici olarak özel ilgiye hakkı olduğunu düşünmektedir.

- Madde bağımlılı̆̆ı sık görülür.

- Anormal düzeyde kıskançtır (birlikte olduğu kişinin sürekli kendisiyle birlikte olmasını veya nereye giderse gitsin haber vermesini bekler) (Subaşı, Akın, 2011).

$\mathrm{Bu}$ ortak özellikler toplumlar ve kültürlere rağmen yetişme koşulları ve sosyal statüye rağmen politik, ekonomik ve dinsel farklılıklara rağmen insanlarda görülebilmektedir. Özellikle ve çoğunlukla da erkeklerde. Bu farklılıklara rağmen bu özelliklerin ortak olarak insanlarda bulunması bizim bu sorunu kimlikler üzerinden değerlendirmemizi haklı ve doğru kılmaktadır. Üzerinde durmak istediğimiz konu ise bu farklılıklara rağmen insanları ortak bakışlara sürükleyen etmenlerin neler olduğu. Bu sorunsal bizi ortak algılara ve algıları biçimlendiren kitle iletişim araçlarına ulaştırmaktadır.

\subsection{Erkek Tanımlaması ve Bakışı}

Özgür insan, hayatına kendi hür iradesiyle aldığı kararlar doğrultusunda yön veren insandır. Özgürlüğün temel koşulu halindeki eylem, kişinin kendi plânlarına göre eylemesi, gelecek için amaçlar saptayarak, bunu şimdiecde dışlaştırmasıdır... (Eliuz, 2011).

Özgürlüğün belirleyici olan kriteri konumundaki hür irade ve hür irade ile gerçekleştirilen eylemlerin belirleyeni sorgusu bizi algı sürecine ve erkek egemen bakışlara götürmektedir.

...ama geleneksel kadın rolü içinde bunu gerçekleştirmek mümkün değildir. Bundan dolayı, kadın özerk değil görelidir. Kadınlar kendilerini erkek olmadan düşünemediklerine ve düşünülmediklerine göre, erkeğin özne ve mutlak olduğu yerde, kadın yalnızca erkeğin eksik ötekisi`dir. Öteki de, kendi bağımsız özüne sahip bir şey olarak görülemez (Eliuz, 2011).

Ötekileşme kavramı içerisinde kadın sahip olduğu bireysel değerini yine söz konusu sosyal çevre içerisinde üretilen algılara göre şekillendirmektedir. Dolayısıyla kadının öteki olması da birey olması da bir mücadele içerisinde kendi özgürlük arayışı içerisinde olması da ona sosyal çevresinin tanımladığı sınırlar çerçevesinde gerçekleşmektedir. Bu nedenle kadının özgürlük arayışlarını salt kendi başına değerlendirmek mümkün değildir. Özelliklede internet, TV gibi kitle iletişim araçları kadını bir obje ve 
istismara açık bir potansiyel olarak sunması kadına bakışı ve kadını kendine rağmen kendini sınırlandırarak konumlandırmasına neden olmaktadır.

Kadının biyolojik farklılıkların ötesinde kadın olduğu gerçeğiyle uzlaşması ve özgüvenini yenileme çabası içerisine girmesi şarttır. Ancak o zaman kendiliğinin farkında bir birey olarak, kendi ayakları üzerinde durma ve önce ekonomik sonra da tinsel özgürlügüne ulaşma mücadelesi içerisinde kendilik değerlerinin farkındalığında yaşar ve kadın olma yazgısını kabullenmeyerek verili olanları aşar (Eliuz, 2011).

Kadın kimliğinin verili olanın dışına taşması onun açısından kadına verilen yeni bir kimliği taşıması ile mümkündür. Bu kadınlar için özgürlük ortamının söz konusu olmadığını yinelemektedir. Çünkü bu kazanım ona verili (kadın için tanımlanan yeni bir kimlik) bir kazanımdır.

Sonuç olarak özgürleşme yolunda özellikle de modern dünyada sosyal olarak üretilen farklılıklara bir tepki olarak ortaya çıkan kadının bireyleşme süreci; yine erkeklerin izin verdiği ölçüde büyüme ve gelişme fırsatı bulmaktadır. Burada kadının özgürlüğü ya da ötekileşmesi bir bakıma erkek bakışına göre belirlenmekte ve üretilen algılarla şekillendirilmektedir.

Erkeğin tavrını ve kadının ihtiyaçlarını belirleyen ve bu noktada algıları şekillendiren ise kitle iletişim araçları olmaktadır. Kitle iletişim araçlarının yaygın ya da bugünkü anlamıyla hiç olmadığı dönemlerde ise algıyı şekillendirmek; normlar, öğretiler ve dinler üzerinden yürütülmektedir. Oysa aynı süreçte ekonomik, politik, kültürel ve toplumsal anlamda ortaya çıkarılan göstergelerin süreci etkilediği bilinmektedir. Günümüzde ise kitle iletişim araçları ekonomik, politik, kültürel ve toplumsal anlamda hiç bir fark gözetmeksizin algıları etkileyebilmekte ve ürettiği alternatifler ile kadına kendi sınırlarını aşan fakat farklı sınırların içerisine hapseden yeni kapılar açmaktadır.

\section{BÖLÜM: Sosyal Medya ve Sosyal Medyanın Kadına Yönelik Şiddetin Durdurulmasındaki Rolü}

\subsection{Günümüzde Sosyal Medya}

Görüntü, hayatımızın tüm bölümlerinde yer almaktadır. Okuduğumuz basılı kitaplar, gazete sayfaları, alışveriş merkezlerinden sinemalara, evlerimizdeki cam ekrana ve tüm internet kaynaklarına kadar her yerde, hareketli ya da durağan görüntülerle karşılaşılmaktadır. Durağan ya da hareketli tüm görüntüler, hatta gerçekte var olamayanlar da var olan bir nesnenin ya da bir düşüncenin, belirli bir yüzey üzerinde yeniden üretimidir. İmgeler bize asıl dünyayı değil, seçilmiş bir dünyayı gösterir ve gösterilenler, gerçeğin temsilleri, yeniden sunumlarıdır (Leppert, 2002). 
İnternet süreciyle başlayan küresel ölçekte enformasyon akışının son noktalarından biri olan toplumsal paylaşım ağları, zaman ve mekan kavramlarını bir kere daha yapı bozumuna uğratarak bireysel ve toplumsal hayatın yeniden yorumlanmasını sağlamışlardır. Bu nedenle küresel bir ağ döngüsü içerisinde gerçekleşen bu yeni sürecin tanımlanması ve anlaşılmasına denk düşen en anlamlı toplum tanımlaması 'ağ toplumu'dur. Manuel Castells'in deyişi ile, "bireyler artık küresel ve yerel olarak örülmüş, birbiriyle bağlantılı ağ toplumu içinde yaşamaktadır" (Binark ve d., 2009) (akt: Babacan, Haşlak, Hira, 2013).

İnsan, tarihi serüveni içerisinde yaşadığı dönem ve zamanın ruhuna uygun iletişim biçimlerini ve araçlarını bir biçimde üretmiştir. Söz konusu bu üretim süreci bir döngü içerisinde birbirine eklenerek, birbirini geliştirerek ve çoğu kez dönüştürerek yoluna devam etmektedir.๑“'Yeni şeyler yeni sözcüklere ihtiyaç duymaktadır. Fakat yeni şeyler aynı zamanda derin anlamlara sahip olan eski kelimeleri de değişikliğe uğratmaktadır. Telgraf ve baskı makinesi haber (information) sözcügüüle kastettiğimiz manayı değiştirmiştir. Televizyon, siyasi tartışma, haberler, kamuoyu terimleriyle ifade ettiğimiz manaları değişikliğe uğratmıştır. Bilgisayar haber sözcüğünün manasını bir kez daha değiştirmiştir" (Postman, 2004) (akt: Babacan, Haşlak, Hira, 2013).

Bireylerin özgürce kendilerini tanımlamalarına ve ifade edebilmelerine olanak tanıyan sosyal paylaşım ağları kullanıcılar tarafından birçok amaçla kullanılmaktadır. Kullanım amaçları kişiden kişiye değişim gösterebilirken, toplumsal düzeyde de farklı amaçlarla kullanılabilmektedir. Bireylerin daha çok bastırılmış toplumsal yönlerini yansıttıkları kimlik oluşturma (oluşturulan profiller kimlikler hakkında bilgi vermektedir) iletişim kurma, eski arkadaşları bulma ve eşlenme gibi başlıklar sayılabilir. $\mathrm{Bu}$ anlamda toplumsal paylaşım ağları pratiklerinin yaygın kanaatin aksine bireyleri sosyalleştirmediği, ancak gerçek hayatta var olan sosyal ilişkilerin devam ettirilerek, güçlendirdiğini belirtmemiz gerekmektedir. Başka bir ifadeyle toplumsal paylaşım ağlarında kurulan iletişimin veya tanışıklığın daha çok gerçek hayatta yüz yüze iletişim kurabilen insanlar arasında gerçekleştiği görülmektedir. “Toplumsal paylaşım ağlarının çoğunda kullanıcılar yeni insanlarla karşılaşma ve iletişime geçme amacının ötesinde mevcut arkadaşları veya tanıdıkları ile de iletişimi sürdürme amacını gütmektedirler" (Boyd ve Ellision, 2007 akt. Binark ve d., 2009) (akt: Babacan, Haşlak, Hira, 2013).

Sosyal medyanın gerçeği dönüştürerek ürettiği yeni gerçeklikler birçok olumsuz durumu da beraberinde getirmiştir. Sosyal medyada 
üretilen ve paylaşılan içeriklere bakıldığında bu kanı desteklenmektedir. Öte taraftan sosyal medyanın sunduğu yeni gerçeklikler yeni kimlikleri de beraberinde getirmektedir. Ve üretilen bu yeni kimlikler toplum, kültür, ekonomik durum, politik bakış, sosyal çevre, cinsiyet gibi etmenlere bağlı kalmaksızın tüm insanlara yakın olabilmektedir. Sosyal ortamın tüm insanlığı kuşatan kapsayıcılığı onun bakışları ve algıları şekillendirdiği gerçeğini pekiştirmektedir.

Sınır tanımaksızın tüm insanlara ulaşabilen sosyal medyanın sahip olduğu bu güç, onu yeni kimliklerin oluşmasında diğer belirleyenlerin (toplum, geçmiş, sosyal çevre vb.) yanında öncelikli kılmaktadır. Sosyal medyanın sahip olduğu bu konum dikkatlerin sosyal medyada paylaşılan içeriklere ve sosyal medya kullanımına verilmesine olanak sağlamaktadır.

"Kullanım amaç ve pratikleri yer yer değişen sosyal/yeni medyanın, toplumsal yapıyı demokratikleştiren, kamusal alanda iletişimsel eylem pratiğini zenginleştiren ve geliştiren amaçlarla ve şekillerde kullanılması yerine, gitgide artan bir oran ve yaygınlıkta cinsiyetçi, homofobik, ırkçı, zenofobik içeriklerin dolaşımı ve yaygınlaştırılması için kullanılması üzerinde durulması gerekmektedir" (Binark ve d., 2009) (akt: Babacan, Haşlak, Hira, 2013).

Kimlik aktaran konumunda bulunan aileler sahip olduğu bu konumlarını gün geçtikçe yitirmektedir. Bu durumun nedeni ailelerin kimliklerini yitirmesi ve bu kimlik bunalımı içerisinde ailelerin artık genç nesillere nüfus edememesi ile ilintilidir.

Sosyal medya kimlik aktaran konumunda ortaya çıkan boşluğu, sahip olduğu içerikle doldurmaktadır. Sosyal medyanın sahip olduğu içerik ise onun kullanımı ile doğrudan bir ilişki içerisindedir. Algıları şekillendiren ve ürettiği yeni algılarla yeni kimlikler (fakat bu yeni kimlikler içerisinde yaşadığ 1 kültürün sahip olduğu kimliklerle tezatlık içerdiğinden bir kimlik bunalımından söz edilebilir) üreten sosyal medya insanı ve insanın bakışını da belirlemektedir.

Sosyal medya içerisinde kadın kimliği bir taraftan özgürlüğünün peşinde koşan, kariyer sahibi, ekonomik bağımsızlığını eline almış bir birey olmakla modern bir kimlik olarak sunulmakta diğer tarafta ise bir meta, cinsel bir obje olarak sunulmakta ya da kadına yönelik tartışmalarla onun sahip olduğu konumu belirlemektedir. Fakat tüm bu belirlenimler yönlendirilmiş algılar üzerinden hayat bulmaktadır.

\subsection{Sosyal Medyanın Kadına Yönelik Şiddette Rolü}

Özellikle bilgisayar ve bilgisayar dolayımıla internet, iletişim serüvenini ontolojik bir dönüşüme uğratmakla kalmayıp, toplumsal yapının 
bütün unsurlarına dokunarak yatay ve dikey bütün geçişlerin yönünü değiştirmektedir. Bu yönüyle insanlık tarihinde varlığının çok yeni olmasına karşın internet, hiçbir alan ve konuyla sınırlandırılamayan, bütün dünyanın sınırlarını aşarak yepyeni bir ortamın oluşmasını sağlamıştır. Kendine özgü kültürel bir dünya yaratan söz konusu bu yeni ortam, beraberinde yeni toplumsal ve bireysel ilişki biçimlerinin, yeni kimliklerin ortaya çıkmasının ve yeni bir kültürel ortamın oluşmasının itici gücü olmuştur. Bu yönüyle internet, "bireylerin ve sahip oldukları bilgisayarların etkileşimi sayesinde, büyük miktardaki verinin sanal düzeyde ama dünya ölçeğinde yayılmasını sağlamıştır" (Aydoğan, 2010) (akt: Babacan, Haşlak, Hira, 2013).

Bu özgürlük ortamı, bireylerin sadece gündelik haber, bilgi veya iletişim amacıyla değil, siyasi, ideolojik, iktisadi, kültürel hemen her alanda katılımını sağlamaktadır. Bu yeni medya düzeninin artık ses getiren ve hızlı yayılan bir yapıya sahip olduğu açık bir gerçekliktir. Bu yeni ağ ve habercilik; düzenin belirlediği tüm kuralları delmeye ve örülmüş duvarları yıkmaya hazırlanan dinamik bir yapıya sahiptir. Haberlerini yayınlarken kendinden başka bir editörün olmadığ 1 ve haberine oto-sansür uygulanmayacağı bir alandır (Babacan, Haşlak, Hira, 2013).

Sosyal medyanın toplumsal olarak var olan tüm dinamikleri alt üst eden yapısı onun ulaşılabilirliği ve ulaştığı mecraları şekillendirmesi ile ortaya çıkmaktadır. Bir bakıma sosyal medya içerikleri kimlikleri etkilemekte ve dönüştürmektedir. Bu dönüşüm kullanılan ve paylaşılan içeriklerle doğru orantılıdır.

2.3. Kadına Yönelik Şiddeti Önlemede Sosyal Medyanın Önemi ve Sosyal Medya Çalışmaları

Kitle iletişim araçları kanalıyla daha çok monolog biçimde gerçekleşen iletişim sürecinin, bu araçların gücünü ellerinde bulunduranlar tarafından gerçekleştirildiği iddia edilmekteydi. Oysa iletişim biçiminin söz konusu klasik anlamından köklü biçimde koparak, iletişim sürecinin yapısal bir dönüşüme uğraması sonucu, interaktif, çok boyutlu ve karşılıklı bir iletişim süreci başlamış oldu. Buna paralel günümüzde toplumsal hayatta yaşanan birçok gelişme artık direkt ya da dolaylı biçimde söz konusu yeni medya biçiminden etkilenerek ve ya esinlenerek şekillenmektedir (Kahraman, 2009).

Sosyal medya sahip olduğu "katılımcılar, açıklık, konuşma, toplum, bağlantılılık, erişim, erişilebilirlik, kullanılırlık, yenilik ve kalıcılık gibi özelliklerinden dolayı kadına şiddeti önlemede tercih edilen bir mecra olmaktadır. Üstelik Türkiye, Avrupa'nın internette en çok zaman geçiren 
ülkesi durumundadır. Sosyal medya için dünya çapında rakamsal bir değerlendirme yapıldığında şöyle bir tabloyla karşılaşılmaktadır;

- İnternette sosyal medya pornoyu geride birakmıştır.

- Twitter'ın geçtiğimiz yıl için büyüme oranı: \%1.500

- Dünya üzerinde her üç kişiden ikisi sosyal ağları ziyaret etmektedir.

- Her gün Youtube'ta 100 milyon video izlenmekte ve her dakika 20 saatlik video yüklenmektedir.

- Her gün Facebook üzerinde 8 milyar dakika geçirilmekte ve 285 milyon adet içerik paylaşılmaktadır.

- 350 milyon aktif kullanıcısı ile Facebook bir ülke olsaydı Çin ve Hindistan'dan sonra dünyanın en kalabalık 3. ülkesi olurdu.

- 6.7 milyar tweet gönderildi.

- İnternet kullanıcilarının sadece \% 65.1'i e-posta kullanmakta, sosyal ağları kullananlar ise $\% 68$ 'dir.

- 14 milyondan fazla kullanıciyla Türkiye Facebook'ta en aktif 3. ülkedir.

- Friendfeed'in Dünya'da en popüler olduğu ülke Türkiye. (Kahraman, 2009)

Kadına yönelik şiddet olgusu, geçmişte olduğu gibi günümüzde de süregelen ve gelecek nesiller açısından da öngörülen bir tehlikedir. Genel yaklaşımla, kadına yönelik şiddetin önlenmesinde sosyal, ekonomik, kültürel, psikolojik alanlarda disiplinler arası çalışmalar ve araştırmaların artırılması, sanatın birleştirici ve bütünleştirici rolü ile desteklenmesi zorunluluk haline gelmiştir. Sanat olgusunun, sosyal medya, yeni medya, basılı medya ve yayıncılık alanlarını da kapsayan tüm bileşenleriyle sosyal sorumluluk projeleri üzerindeki pozitif katkısı; bu akımların mesaj iletme gücü de kullanılarak, sosyal sorumluluk projelerinin sanat yoluyla ve ya aracılığıyla yapılmasında fayda görülmektedir.

Günümüzde sosyal sorumluluk kapsaminda üretilen projelere bakıldığında sanatsal kaygıların yanı sıra kampanya için ayrılan bütçeler de dikkat çekmektedir. Örneğin Avon, kadınlara yönelik şiddeti önlemek için 1.75 milyon dolarlık bir bütçe ayırmıştır. Bu bütçe ile Cornell Hukuk Fakültesi'nde AVON Küresel Kadın ve Adalet Merkezi'ni kurmayı amaçlayan Avon bu yeni merkezinde kadınlara ve genç kızlara karşı şiddeti engellemeye yönelik adalet mekanizmalarına erişimi iyileştirmek üzere hakimler, hukuk uzmanları, devlet kuruluşları ve sivil toplum örgütleriyle beraber çalışacak. Ayrıca, AVON Birleşmiş Milletler Kadınlar için Gelişim Fonu'na (UNIFEM) yardımlarını, BM Güven Fonu'na 2008' de bağışlanan \$1 milyon'luk tutarı $\$ 250.000$ daha bağışlayarak genişletiyor. Bununla birlikte, 
AVON'un bugüne kadar kadınlara yönelik şiddeti önlemek için dünyadaki toplam bağış tutarı \$14 milyon üzerine ulaşıyor.

2004 yılında başlatılan ve halen daha dünyanın 45 ülkesinde uygulanan "Aile İçi Şiddete Karşı Mücadele Programı", AVON'un kadınlara yönelik şiddeti sonlandırmaya yönelik bağlılı̆̆ının bir göstergesi olarak durmaktadır. AVON, ayrıca dünyanın 13 ülkesinde kadınlara yönelik şiddet konusunda yerel UNIFEM ofisleri ile birlikte çalışmaktadır. Bu başarılı girişimlerin arkasında, AVON'un şirket ağında bulunan 6 milyona yakın Satış Temsilcileri'nin kampanyaya karşı yoğun destekleri yer alıyor.

UNIFEM, Birleşmiş Milletler Kadınlar için Gelişim Fonu, kadınların güçlenmesini ve cinsiyet eşitliğini sağlamayı amaçlayan yaratıcı program ve stratejilere finansal ve teknik yardımda bulunmaktadır. Girişimlerinin merkezine kadınların insani haklarının gelişimini koyan UNIFEM, etkinliklerini kadın yoksulluğunun azaltılması, kadına yönelik şiddetin sonlandırılması, kadınlar ve genç kızlar arasındaki HIV/AIDS'in yaygınlaşmasının önlenmesi ve barış ve savaş halinde demokratik yönetimlerde cinsiyet eşitliğinin sağlanması üzerine odaklıyor.

Bunun yanı sıra AVON Global Marka Elçisi ve AVON Kadın Vakfı Onursal Başkanı Reese Witherspoon, Global Forum'dan hemen önce düzenlenen bir basın toplantısında, $\mathrm{AVON}^{\prime} u n$ yeni bir bağış toplama ürünü olan "Kadınları Güçlendirme Kolyesi" ni tanıttı. Dünya üzerinde yaklaşık 1 milyar kadının şiddete maruz kaldığını belirten Witherspoon, "Kadınları Güçlendirme Kolyesi, tüm kadınlar için harekete geçmek ve dünya çapında kadınlara yönelik şiddeti önlemek için birlik oluşturmanın en kolay yolu! AVON Vakfı Onursal Başkanı, bir kadın ve bir anne olarak bu girişimi desteklemekten onur duyuyorum."dedi

2009 yılında piyasaya sürülen bu kolyeden elde edilen gelir daha önce 2008 yılında üretilen "kadınları güçlendirme bilekliği"nden elde edilen 4 milyon dolara eklenerek aile içi şiddetle mücadele programlarına destek vermektedir. Firma bu çabaları yine Avon'un Satış Temsilcileri aracılığı ile yürütmektedir.

Avon'un kadına yönelik şiddeti önleme adına ürettiği bir diğer projede Refuge firması ile ürettikleri "Support a Frend". Aile içi şiddette kadınlara yardım amacıyla kurulan Refuge ile Avon'un ortaklaşa yaptıkları bu proje "Bir Arkadaşınıza Destek Olun" sloganı ile hazırlanan interaktif videodan oluşmaktadır.

Hedef kitlesi şiddet mağdurlarının yakın çevresi olan kampanya ile şiddete maruz kalan kadınlara nasıl yaklaşılması gerektiğine dair mesajlar veriliyor. Bu nedenle de kampanyanın adı "Bir Arkadaşınıza Destek Olun" 
olarak belirlenmiş. Ana kampanyanın ismi de istatistik sonuçlarından elde edilen bir gerçeği, her 4 kadından 1'inin hayatlarının bir aşamasında aile içi şiddete maruz kaldığını hatırlatması için tercih edilmiş. 8 tanesinde soru bulunan toplam 9 videonun hazırlandığı kampanya için video çalışmalarını Fransız müzisyen ve animasyon film yönetmeni Fursy Teyssier gerçekleştirmiş.

Kadına yönelik şiddeti engellemeyi amaçlayan bir diğer kuruluş da Un Women. "Turuncu Giyiyorum Çünkü..." sloganı ile dünya genelinde hayat bulan bu kampanya milyonlarca insana kısa süre içerisinde ulaşmış ve kampanyaya aktif olarak katılmaları sağlanmıştır.

One Billion Rising adı ile tüm dünyada aktivistlerinin bulunduğu kuruluş, 14 Şubat 2013 tarihinde "Kadına Yönelik Şiddete Hayır" başlığı ile tüm dünyada 1 milyar insanın dans etmesi amaçlı bir organizasyon düzenlemiştir. Kampanya süresince Twitter, Facebook gibi sosyal medya bileşenlerini etkin bir biçimde kullanan kurum 207 ülkeden katılım almış, sosyal medya adına adından söz ettirecek bir kampanyaya imza atmıştır.

\section{Sonuç}

Bireyin fiziksel, bilişsel, sosyal ve psikolojik gelişiminin birbiriyle ilişkili olarak ilerlemesinin sonucunda oluşturulan (Köker, 1997) kimlik tanımındaki tüm belirleyenler artık günümüzde en yaygın kitle iletişim aracı konumunda bulunan sosyal medya tarafından belirlenmektedir.

Kadına yönelik şiddet, cinsiyete dayanan, kadını inciten, ona zarar veren, fiziksel, cinsel, ruhsal hasarla sonuçlanma olasılığı bulunan, toplum içerisinde ya da özel yaşamında ona baskı uygulanması ve özgürlüklerinin keyfi olarak kısıtlanmasına neden olan her türlü davranıştır (DSÖ, 1993). Bu davranışların tedavi edilebilmesi ve kadına yönelik şiddetin bitirilmesi adına üretilebilecek tüm projeler kitle iletişim araçları üzerinden duyurulduğunda proje hem ulaşılabilirliği hem de tesiri yönünden sağlıklı bir süreç geçirmektedir.

Kadına yönelik şiddet olgusu, geçmişte olduğu gibi günümüzde de süregelen ve gelecek nesiller açısından da öngörülen bir tehlikedir. Genel yaklaşımla, kadına yönelik şiddetin önlenmesinde sosyal, ekonomik, kültürel, psikolojik alanlarda disiplinler arası çalı̧̧malar ve araştırmaların artırılması, sanatın birleştirici ve bütünleştirici rolü ile desteklenmesi zorunluluk haline gelmiştir. Sanat olgusunun, sosyal medya, yeni medya, basılı medya ve yayıncılık alanlarını da kapsayan tüm bileşenleriyle sosyal sorumluluk projeleri üzerindeki pozitif katkısı; bu akımların mesaj iletme gücü de kullanılarak, sosyal sorumluluk projelerinin sanat yoluyla veya aracılığıyla yapılmasında fayda görülmüştür. 


\section{Kaynakça}

ARKONAÇ, S. A. (1998) Sosyal Psikoloji, Alfa, İstanbul.

AYDOĞAN, Filiz (2010), ๑'Íkinci Medya Çağı'nda Gözetim ile Kamusal Alan Paradoksunda İnternet', İkinci Medya Çağında İnternet, der. F.Aydoğan, A. Akyüz, İstanbul, Alfa Yayınları

BABACAN, Emin, Mehmet, HAŞLAK, İrfan, HİRA, İsmail (2013), Sosyal Medya ve Arap Baharı

BAKAN, İsmail, KEFE, İlker (2013), Kurumsal Açıdan Alg1 Ve Alg1 Yönetimi

BİNARK, Mutlu, ve diğerleri (2009), Toplumsal Paylaşım Ağı Facebook: “Görülüyorum Öyleyse Varım", İstanbul, Kalkedon Yayınları.

ERASLAN, Uludağ, Reyhan, 2013, Sosyal Medya Her An Ve Her Yerde Görünür Olmak, İstanbul Kültür Üniversitesi, Sanat ve Tasarım Fakültesi, İletişim Tasarımı Bölümü, İstanbul, Ayrıntı Yayınları.

ELIUUZ, Ülkü (2011), Cinsel Kimlik Paniği: Kadın Olmak. Fusion, Information Fusion 4, ss.231-234.

Johansson, L.R.M., Xiong, N., (2003). Perception Management: An Emerging Concept for Information

LEPPERT, Richard. (Çev: TÜRKMEN, İsmail) (2002). Sanatta Anlamın Görüntüsü, İmgelerin Toplumsal İşlevi.

METINN, Abdullah (2011), Çankırı Karatekin Üniversitesi SBE Dergisi 2 (1): 74-92

SANKIR, Hasan (2010), Toplumsal Cinsiyet Rollerinin Anlamlandırılış Biçiminin "Kadın Sanatçı Kimliği"nin Oluşum Sürecine Etkileri.

SIRAKAYA, Hümeyra, Amine, Ergenlerde Kimlik Bunalımı 2013-2014

SUBAŞI, Nüket, AKIN, Ayşe (2011), Kadına Yönelik Şiddet; Nedenleri ve Sonuçları

TAYANÇ, Dilek Akıcı (2010), Modernizm ve Postmodernizmin Kadın Kimliği Üzerindeki Etkisi

Postman, Neil (2004), Teknopoli, (çev. Mustafa E. Yılmaz), İstanbul, Gelenek Yayınları

http://www.cosmoturk.com/guzellik/avon-global-marka-elcisi-reese-witherspoon-yenikuresel-seferberlik-cabalarini-baslatiyor-aefbj.html

http://bigumigu.com/haber/avon-ve-refuge-den-kadina-iddete-karsiinteraktif-kamp

http://www.unwomen.org/en

http://www.onebillionrising.org/about/campaign/ 
A. KARATAY, A. KARATAY $\mid 36$ 